Finally, "Bürgertum, Borgare, Bourgeoisie: the Concept of the Middle Class in Europe and America" considered several distinct representations of the middle class. Madeleine Hurd (Harvard University) compared the German and Swedish middle classes, calling for a much more complex understanding of the lack of liberal success in nineteenth-century Germany. Fred McKitrick (Columbia University) concluded that the integration of German artisans into a modern industrial economy and into the broad middle class after 1945 was not brought about by a free marketplace. Rather, it was accomplished under the direction of corporate forms of organization which are generally assumed to be economically inflexible and politically illiberal. The effort succeeded because a strong sense of artisanal identity and tradition had been preserved within a corporate context that was high pragmatic.

Although the conference was not organized around a central theme, several conclusions emerged which are relevant to the work of social and labor historians. Many agreed on the need for more East-West comparisons in European studies, and the need for greater emphasis on Europe's relations with other regions of the world. Continuing attention should be paid to the contributions of poststructuralist social and cultural theory in understanding the lives of working-class men and women and the history of labor movements.

\title{
Organization of American Historians
}

\section{David Morrison}

University of Cincinnati

The 1992 Organization of American Historians (OAH) annual meeting, held in Chicago. featured a wide range of papers and panels devoted to labor history. The conference opened with a retrospective look at "Race and Class in Early America: The Works of Gary B. Nash." Like many others, this panel paid tribute to past idioms while also exploring new approaches. Richard Dunn (University of Pennsylvania), who taught Nash at Princeton, began the session by noting Nash's work both as an archival scholar and in high-school curriculum development. Allan Kulikoff (Northern Illinois University) praised Nash for developing a model of class formation in colonial America but saw the need to bring rural peoples and household relations into the story. Similarly, Jean Soderlund (University of Maryland, Baltimore County) lauded Nash's early integration of race and class while lamenting his neglect of gender.

In "Labor at the Ballot Box," the papers presented intriguing approaches to labor's source of political power. "Labor and the Democracy of Bryan and Wilson: The Origins and Impact of a Progressive Era Alliance" by Julia Greene (University of Missouri-Kansas City) examined the relationship between the American Federation of Labor (AFL) and the Democratic party. Greene found that the AFL's inability to deliver its members' votes, coupled with its increasing antistatism, led the Democrats to abandon the union and seek a direct alliance with the working class. Eric Leif Davin (University of Pittsburgh) presented "SWOC Takes 
Power in Steeltown: How Democracy and the Union Came to Western Pennsylvania," which described labor's seizure of a moribund Democratic apparatus and later success over the local Republican machine during the depression. "Craft Unions in the Massachusetts Political Arena in the Late 1980's," written by Mark Erlich (Carpenters Union Local 40, Boston) but read by moderator Staughton Lynd (Northeast Ohio Legal Services), related the successful effort by organized labor to unite with women, minorities, and the working poor in defense of the state's prevailing wage law.

Robert Steinfeld (SUNY-Buffalo Law School), Christopher L. Tomlins (American Bar Foundation), and Karen Orren (UCLA) discussed "Labor Regulation in the New World." Each sought to explain the legal framework in which labor was forced to operate. Steinfeld's essay, derived from his book The Invention of Free Labor, traced the effect of the Thirteenth Amendment on contract labor. As late as 1897, he noted, the U.S. Supreme Court upheld laws which compelled sailors to obey the terms of their contracts, but Steinfeld also saw a more general trend toward our modern notion of free labor. Tomlins's "Law, Labor and Ideology in Colonial and Antebellum America" likewise found a postbellum trend toward liberalized standards of free labor, but he contrasted this freedom with an earlier narrowing of workers' rights in the years following the American Revolution. "Labor Regulation and Constitutional Theory in England and the United States," Orren's essay, reached across time as well as the Atlantic to note the similarities between medieval English labor law and twentieth-century American practice.

Harold Woodman (Purdue) moderated a panel on "Convict Labor in the New South." Alex Lichtenstein (Florida International University) and Karin Shapiro (Yale) both discussed convict leasing, but with very different conclusions. Lichtenstein's "Twice the Work of Free Labor? Convict Labor in Georgia's Coal Mines" argued that leasing was woefully inefficient and collapsed of its own weight. Shapiro's "Only the State May Be a Master: The Termination of Tennessee's Convict Lease," on the other hand, found that a groundswell of humanitarian reform, unallied with either unions or farmers, brought about the end of the lease. In "Parchman Plantation: Race, Profit and Punishment in the Modern South," David Oshinsky (Rutgers) explained that conditions on Mississippi's 20,000-acre prison farm, while brutal, were nonetheless an improvement over that state's nineteenth-century leasing program.

The conference concluded with "Rethinking the Origins of Modern Urban Politics: The Impact and the Rise of Labor in Chicago, 1850-1910." John Jentz (Northern Illinois University) and Richard Schneirov (Indiana State University) presented early drafts of an upcoming collaborative work. Jentz's "Where Does Culture Stop and Politics Begin? An Inquiry into Working Class Formation" examined the complex relationship between class and party affiliation. Borrowing from Habermas's construction of the public sphere, he argued that culture and politics remained closely intertwined, so that active labor reform declined as politics absorbed workers' concerns. Schneirov's essay "The Rise of Labor and the Birth of Urban Social Reform in Chicago, from Haymarket to the World's Fair" looked at the connection between working-class unions and middle-class reform groups. While Chicago mugwumps may have viewed labor with disdain, he concluded, they also lifted many reform demands directly from union platforms. Thus, he found that labor's reform impulse survived the brutal repres- 
sion following Pullman and transformed into the Progressive Era movement of the urban middle class.

Finally, the OAH bestowed its Merle Curti Award on David Roediger's The Wages of Whiteness: Race and the Making of the American Working Class (Verso).

\section{Reworking American Labor History: Race, Gender, and Class}

\section{David A. Zonderman}

University of Wisconsin-Madison

On April 9-11, 1992, the State Historical Society of Wisconsin and the Department of History at the University of Wisconsin-Madison cosponsored the conference "Reworking American Labor History: Race, Gender, and Class." The conference brought together over one hundred scholars from across the United States to hear fifteen panels containing forty papers on all aspects of American labor history. The meeting opened up many new avenues of historical inquiry into the lives and labor of previously unexplored working people and the roots of cultural diversity in the American workplace. It challenged all labor historians to consider how the basic social constructs of race and gender, which were entwined in nearly all the papers presented, can broaden the terrain of the discipline in its totality.

The meeting was highlighted by two plenary papers, commissioned by the conference organizers, on the conference's theme as a whole. Robin Kelley's presentation, " 'We Are Not What We Seem': Rethinking Black Working-Class Opposition in the Twentieth-Century South," called on the audience to investigate and analyze the richly textured world of African-American families, neighborhoods, churches, fraternal organizations, and other sites of black self-expression and resistance to racist oppression. Kelley wove together the sources and techniques of labor history, cultural history, and African-American history into a densely packed essay which showed both the wealth of material available for immediate research and the long-range potential which such studies might hold for the future direction of American labor history.

Ava Baron's “On Looking at Men: Masculinity and Working-Class History" discussed the significance of exploring masculinity as an analytical framework for writing labor history, and the contributions of women's history and feminist theory to the formulation of these concepts of masculinity and gender itself. Baron examined how the construction of gender, while frequently linked with women's history research, can be applied very fruitfully to the study of workingmen as gendered subjects and as subject to the ideology of masculinity. Baron further argued that seeing male and female workers as shaped by gendered definitions of themselves, and their interactions with each other, opens up even more fundamental questions about the historical development of the American working class. 